Media Industries 8.1 (2021)

\title{
Gendered Labor in the Neo-Art House
}

\author{
Alicia Kozma \\ WASHINGTON COLLEGE \\ akozma2 [AT] washcoll.edu
}

\begin{abstract}
This article excavates and analyzes women's labor in the neo-art house industry. Focusing on the labor histories gleaned from interviews, I offer a reconceptualization of the art house industry post-digital exhibition transition; detail an initial schema of the challenges facing women-identified laborers in the industry, including gendered divisions of labor and financial precarity; and consider internal advocacy efforts some neo-art house workers have created to advance diversity and challenge sexual harassment, among other social justice issues.
\end{abstract}

Keywords: Women's Labor, Exhibition, Art House, Movie Theaters

Digital film significantly transformed the business of theatrical exhibition for US art house movie theaters. Art house theaters, forecasted to buckle under the weight of this change, responded through mission-driven operational diversification, reemerging as multifunctional community spaces. Post-evolution, women-identified art house employees are more visible in the industry's workforce. From the managing director of the Art House Convergence $(\mathrm{AHC})$, the only art theater industry group in the United States, to the head of the renowned BAMCinematek, women-identified workers are spearheading a new generation of art theaters. This is a significant shift for an industry whose leadership was traditionally male. Yet, little is known about women's labor in the industry.

Exhibition is a persistent segment of media and creative industries, although it does not fit cleanly into preexisting considerations. While Caves defines the creative industries as "supplying goods and services that we broadly associate with cultural, artistic, or simply entertainment value," ${ }^{2}$ movie theaters do not supply per se, they facilitate. Exhibition is as old as filmmaking itself, but despite technological changes, it is not dependent on digital and networked platforms like much of "new" media. Movie theaters have never offered the type of Floridian creative economic regeneration promised by creative industries like game design and web-based platforms and services. Exhibition may be more akin to what Mark Banks 
calls craft-"a range of supplementary, non-artistic jobs, some of which are based on craft skills and processes"3-as it creates the space for filmic art to meet audiences.

Despite its uneasy definitional position, exhibitive labor ${ }^{4}$ carries the hallmarks of work in the media and creative industries. Like Rosalind Gill's new media work, exhibition is seen as cool, exciting, flexible, young, and creative. ${ }^{5}$ Particularly for art theaters, that are widely understood as anti-mainstream, independent, and alternative spaces for highbrow cinema rather than populist movies, exhibitive work carries cultural cache. Concurrently, art houses are known for broadly liberal politics emphasizing equality, tolerance, and inclusivity. This ideological culture is regularly represented in programming. Examples include the Seventh Art Stand, wherein participating theaters screened films from countries subject to President Trump's 2017 travel ban as a corrective to the Islamophobia inherent in the policy; the Mobile Movie Theater, which brings films to communities that cannot physically or economically access movie theaters; and dedicated programming like CinemaQ and CineLatinx, which signal-boost LGBTQ+ film and Latinx filmmakers, respectively. ${ }^{6} \mathrm{Neo}$-art theaters weave liberal politics and ideological positions into their very fabric. This, combined with their focus on film as art rather than commercial product, produces neo-art house culture as rhetorically "special" within the media and creative industries, purporting to successfully straddle the divide between art and commerce.

Unfortunately, the ideology of equality often does not extend to neo-art house workers, as exhibitive labor bears the same burdens as work in other media and creative industries, including "pervasive insecurity, low pay, and long hours,"7 and within it "the discourse of flexibility and creative freedom has been allowed to mask some fundamental inequalities and discriminatory practices." 8 These similarities, however, are understudied as a majority of work about film as creative industry is subsumed under production studies, the subset of media and creative industries research particularly concerned with the entertainment industry. As the name implies, it privileges production, working to demystify the idea of "movie magic" while contributing necessary breadth and depth to understandings of film and television industries. For example, Vicki Mayer's Below the Line and John Thornton Caldwell's Production Culture are both concerned with myriad of support jobs that factor into film and TV production like casting agents, crew, and onset craftspersons, among others. Alicia Malone's Backwards in Heels historicizes women in acting, producing, directing, and writing across Hollywood history, and Erin Hill's Never Done uncovers the lost history of women in production-adjacent roles like script readers and researchers. These valued works have revealed more of the inner workings of film and television and the diverse laborers within them, but the prevalence of production studies as the primary pathway into industrial analysis sidelines greater understanding and analysis of the labor of distribution and exhibition. This article contributes to closing that gap by foregrounding film exhibition as a key component of film economies as creative industry by excavating and analyzing women's labor in what I term the neo-art house industry.

The neo-art house industry is a network of independently interfacing multifunctional movie theaters with diversified programming and operations supporting missions and visions broadened past the traditional role of theatrical exhibitors. As labor ecologies of the neo-art house are understudied, this analysis is based on semi-structured interviews with fifteen 
women-identified workers within a wide-ranging group of theaters across the industry. Participants were recruited via email and snowball sampling from a list of cinemas across the country that have a valued reputation in the industry, a presence at the industry's largest annual event, operated before and after the transition to digital exhibition, and are run as non-profit organizations. The women who responded to interview requests were eager to speak about their experiences in the neo-art house. As one said, "I want to tell you everything because no one's ever asked before."9

Participants and theaters are anonymized via pseudonyms. The age of the participants ranges from twenty-five to sixty-eight years, with an average age of thirty-six years. They have worked in the industry anywhere between one and a half and fifteen years. All identify as women; 27 percent identify as women of color and 73 percent identify as white. At the time of interview, 87 percent work in the industry full-time, 13 percent part-time, 73 percent work in management (administration, programming, fundraising, etc.), and 27 percent work as front-of-house staff (general managers, house managers, projectionists, box office, etc.).

Using Miranda J. Banks' oral history as industrial methodology ${ }^{10} \mathrm{I}$ leverage labor histories to reconceptualize the art house industry post-digital exhibition transition; detail an initial schema of challenges facing women-identified laborers, including gendered divisions of labor and financial precarity; and consider the internal advocacy efforts some neo-art house workers have created to advance diversity and challenge sexual harassment, among other social justice issues. I turn first to outlining the neo-art house industry.

\section{The Neo-Art House Industry}

Art theaters rose to prominence in the 1950s and 1960s alongside an influx of foreign film into the United States. ${ }^{11}$ Often located in urban centers, programming could include repertory classics, foreign and independent film, documentary, and experimental/avant-garde filmmaking. In the 1970s, many art theaters screened exploitation films and pornography in response to shrinking urban audiences in the face of white flight. Art theaters are breakeven businesses that subsist primarily on concession sales; the split on ticket sales is heavily weighted toward the film's distributor. ${ }^{12}$ While the definition of an "art theater" has been historically unstable, the neo-art house theater industry is characterized by three components: fluctuating screen content, industrial intra-connection, and operational diversification and mission expansion. Fluctuating screen content speaks to neo-art theaters' complicated relationship with art film, a legacy from the past. Tino Balio historicizes the rise of US art theaters as a partial response to the "transition in American moviegoing from a mass family entertainment to a minority art form."13 Emerging from this change was the "Lost Audience":

mature, adult, sophisticated people who read good books and magazines, who attended lectures and concerts, who are politically and socially aware and alert [and whom were] literally driven out of the motion picture theater by the industry's insistence on aiming most of its product at the lowest level. ${ }^{14}$ 
To capture this "lost" audience, art theaters screened the anti-mainstream content that came to define them. ${ }^{15}$

Art theaters and art film have long been mutually constitutive. John Twomey described art theaters by their programming: "films from other countries, reissues of old-time Hollywood 'classics', documentaries, and independently made films on offbeat themes" (240). Barbara Wilinsky describes the role "art film theaters played in shaping the parameters for and the uses of art cinema." 16 Thomas Elsaesser also notes that art films are defined by the art house: "in fact, it was the US distribution practice of the art-house circuit which gave the term 'art cinema' its currently accepted meaning."

While historically art film was inextricably linked to art theaters, the contemporary connection between art films and art theaters is more fluid. Art film thrived in 2017, but not necessarily in art theaters. Art films, known industrially as specialty films-indie, foreign, and/or documentary films that open in limited release (599 screens and under) and/or were acquired or produced for distribution by an independent distributor or a studio's specialty divisiongrossed US\$520 million in 2017. ${ }^{18}$ Sixty-one percent of that came from major independent or studio specialty divisions licensing films to mainstream theaters, as chain exhibitors increasingly exhibit films traditionally reserved for the art house.

The dissolution of boundaries between content type and exhibition space is reciprocal, as some neo-art theaters now show select mainstream, first-run films as a push-back against the cinematic presence bleed that have undermined them for years. While this does not bestow "art film" status onto these movies, it can imbue them with the "image of prestige and culture associated particularly [with] art film theaters, [helping] elevate cinema to the level of an art form." ${ }^{" 19}$ Resultingly, neo-art theater on-screen content fluctuates between art and mainstream films, creating a transitory cinematic space that can no longer be understood solely by its exhibitive content.

The second component node bounding the neo-art house industry is its recent interconnection. The art theater industry has always been fairly diffuse. Most theaters are one of their kind in their given area and are run as independent entities, as independence has facilitated a disconnected industry. ${ }^{20}$ Theaters may never have contact with one another, and art theaters and the North American Theatre Owners-the trade organization for theatrical exhibitors-have a complicated relationship that often leaves art theaters out of their purview. However, in 2006, the Michigan Theater Foundation founded a group called AHC, partially as an attempt to bring the scattered industry together. That same year, representatives of AHC and fourteen other art houses met in person. By 2008, these theaters decided to hold a yearly meeting. AHC now holds an annual meeting, regional seminars, and exhibition industry events and facilitates a national list serv to help connect art theaters all over the country. Somewhat confusingly, the organization and the conference are called AHC; herein, I refer to the organization as $\mathrm{AHC}$ and the conference as the Convergence. The group is pivotal for art house exhibition, offering the only mass interface for the industry's interconnectivity, helping to foster national conversations, partnerships, and networks across a diverse exhibitive system where theaters can simultaneously be supported while retaining their independence. This connection is a critical characteristic of the neo-art house industry. 
This industrial support system, of sorts, faced its first major test with the 2012 announcement of the end of $35 \mathrm{~mm}$ film production. ${ }^{21}$ Overnight, many art houses found themselves scrambling to keep their doors open. ${ }^{22}$ Digital film radically transmuted art house exhibition. To accommodate this seismic shift, many theaters transformed into non-profit organizations, broadening their missions in the process. ${ }^{23}$ As non-profits, theaters needed to push beyond screen content. Programs and corresponding positions in education, outreach, community engagement, fundraising, event hosting and venue rental, and film festival hosting defined the multipronged approach art theaters took toward their economic viability and community presence. Operational diversification and mission expansion, then, form the final component of the neo-art house industry. More than fluctuating screen content and industrial interconnectedness, this had significant impact on women's labor in the neo-art house industry.

\section{Non-Profit Selective Mapping}

The non-profit neo-art house was dubbed the "new model" art theater. ${ }^{24}$ The pivot to nonprofit structure was initially an economic response to the financial hurdles posed by purchasing digital projection equipment. Non-profit fundraising models like membership drives and capital campaigns underwrote required purchases. However, neo-art houses now significantly depend on raised revenue to supplement and strengthen operational funds. In 2017, 48 percent of neo-art house theater budgets stemmed from contributed monies. ${ }^{25}$ This is critical economic infrastructure, as ticket and concession sales are no longer sufficient in maintaining a break-even operating budget. To cultivate multiple revenue streams, theater operations have shifted in fundamental nature and structure. Gone is the triangulated arrangement of manager, projectionist, and box office staff that supported a single-focus mission of ticket and concession sales. Today, neo-art house leadership positions are commonly Chief Executive Officer (CEO), Chief Development Officer, Chief Financial Officer, Chief Marketing Officer, Program Director, Facilities Manager, Education Manager/Director, and Membership Manager/Director. While specific job titles and staffing levels vary from organization to organization, a majority of neo-art house theaters follow this model to some degree. ${ }^{26}$

Development, marketing, non-curatorial programs, education, and membership positions are the direct result of a non-profit structure, and they are often occupied by women. While the industry did not quantify the gendered breakdown of its workers, the Convergence offers some general trends. At the 2017 and 2018 conferences, most speakers on programming and film festival panels were men and most speakers on education, marketing, and development panels were women, ${ }^{27}$ revealing a gendered split between creative and operational jobs. Economist Marlene Kim calls this "gender-biased evaluations of skill." ${ }^{28}$ Kim describes the embedded perspective that men's labor requires specific training and skills and is therefore more valuable than jobs traditionally filled by women, stereotyped as utilizing standard skill sets. ${ }^{29}$ Film programmers and male CEOs, skilled in cinematic taste and leadership, respectively, are valued affectively and financially more than women laborers, whose work in education, fundraising, and operations is reminiscent of women's traditionally devalued and marginalized work in child-rearing, managing household finances, and homemaking. 
Non-profit salaries are largely dependent on three variables: an organization's general operating budget, metropolitan statistical area (MSA), ${ }^{30}$ and hierarchical job responsibilities. MSA aligns salaries with the cost of living in a given area: non-profit salaries in expensive urban areas are higher than those in less expensive locations. This formula is unevenly applied in neo-art houses as women's job responsibilities and corresponding compensation vary widely. For example, Idie and Paige have the same job-Director of Operations-at different theaters. Idie's city has a lower cost of living, and her theater has a smaller operational budget. Idie supervises one person and makes US\$58,000 per year. Paige supervises twenty-two people and makes US\$40,000 per year.

Importantly, Paige's salary was raised to US\$40,000 to accommodate a male direct report. Despite regular requests, she was given a raise only when her CEO wanted to hire a new male employee who asked for US\$40,000. Paige, as the new employee's supervisor, had to receive a raise to maintain supervisor-supervisee compensation hierarchy. Similar discrepancies exist at the CEO level. Tandy, Tessa, and Betsey are all CEOs, all live in MSAs with similar cost indices, and all work for organizations with similar size budgets. Yet, their salaries vary tremendously: US\$150,000, US\$45,000, and US\$50,000, respectively. Tessa makes US\$45,000 a year and lives in one of the most expensive MSAs in the country. She can "afford" to be paid her salary because she lives with family. If she had to pay rent in addition to her other regular expenses, her salary would be woefully inadequate. ${ }^{31}$

Co-workers are also subject to capricious fluctuations. Anna Marie and Angelica both work part-time at the Midwest Film Show. Anna Marie is the Assistant Manager and is responsible for all front-of-house operations, inventory, supervising ten staff members, projection, and special events. Angelica is the theater's graphic designer and a projectionist/box office staff. Angelica makes US\$12,000 a year and Anna Marie, her direct supervisor, makes US\$9,000 a year. While both have second jobs, their cumulative salaries do not come close to their city's average US\$58,000 salary.

Differences between job responsibilities and corresponding salaries are significant issues in non-theatrical non-profits. But when neo-art houses mapped a non-profit tax designation onto exhibition to enable fundraising, little attention was paid to the shift's industrial impacts. The industry neglected to replicate the controls that exist to decompress compensation and advance equitable job function in non-theatrical non-profits. Organizations like the Chronicle of Philanthropy, the National Council of Nonprofits, the Foundation Center, the Association of Fundraising Professionals, and GuideStar regularly compile compensation surveys by gender, mission type, state, and MSA, benchmarking the non-profit industry and giving workers critical information for individual and collective bargaining. The neo-art house industry has not invested in these controls or explicitly translated this work for their own structures. Pay setting, then, cannot move outside the context,

... in which various groups compete for higher pay, those with the least amount of power-usually low-paid workers, many of whom are women- . . have the least ability to raise their pay by using market wage rates to their advantage. ${ }^{32}$

Neena, Western Cinema City' Membership Director, sums up: "We don't have salary ranges. I don't know what my top salary is. I don't know what I could possibly make, and I don't know how to get there." 33 
A contributing factor is the lack of concrete industry leadership. AHC is an intra-connected space, but it does not offer standards or guidance on organizational or compensation structure; there is no industry entity that does this. Non-profit neo-art theaters have not traditionally abided by basic non-profit organizational charts; titles tend not to correspond to either responsibility or compensation in expected ways. One participant had a director title for middle-management responsibilities, one a manager title for director-level responsibilities, and one a Vice Presidency for CEO-level responsibilities. Without industry-wide standards for job titles, descriptions, and salaries, intense discrepancies will persist across organizations.

Neo-art houses utilizing non-profit operational structures without building the corresponding infrastructure for the protection and advancement of workers is a new form of risk-shifting. Traditional risk-shifting from employers to employees is usually financial, for example, the "increase in defined contribution pension and health insurance plans (in which employees pay more of the premium and absorb more of the risk than do employers)." 34 This new riskshifting function asks neo-art house employees to shoulder the burden of unstructured pay and undefined and varying job responsibilities. Most neo-art houses do not have the critical internal function that monitors inequalities in pay or position discrepancies: human resources (HR). With the exception of a handful of large neo-art house chains that contract with outside firms at a cost prohibitive to most exhibitors, the neo-art house HR function falls to a variety of people: CEOs, financial staff, house managers, or program directors-most of whom are not trained in the functions and skills of HR work. Neo-art house risk-shifting is similar to how project-based workers in media and creative industries cope with the individualization of risk, which requires workers to be self-supervised while incurring the costs for all career development, taxes, insurance, and other workplace compensations. ${ }^{35}$

All participants described an increase in financial precarity as a direct result of the piecemeal mapping of a new non-profit legal and organizational structure. Despite this, the rhetoric of the specialness of neo-art house ideological culture allows theaters to operate in the space between for-profit and non-profit, using the guise of cinema as art to conceal or to deflect labor issues and hide the fact that neo-art house work is work. As creative workers, women in the neo-art house struggle with what Mark Banks describes as "the tension between the need for artists to create an independent nexus of creativity, labor freedoms and skilled, artisanal production while serving commercial masters." ${ }^{36}$ As a result of this tension, the reality of everyday work and its corresponding labor inequities place a distant second to the rhetoric of the specialness of neo-art theaters as artistic entities. However, ignoring exhibitive labor anything but allows precarity, manifest in gendered economics, to remain the dominant structure of the industry.

\section{Impacts of Gendered Economics}

Precarious working conditions, inconsistent organizational structures, and a lack of industry standards have material impacts on women in the neo-art house industry. The salary range of study participants was vast-ranging from US\$9,000 to US\$150,000-with the modal annual salary approximately US\$45,000. This is slightly higher than the nationwide average 
salary for women of US\$41,977. ${ }^{37}$ However, many participants reported that their salary did not satisfy cost of living in their MSA. Regan has a full-time front-of-house position that includes supervising nineteen other staff members. Her annual salary is US\$26,000; she has two additional jobs to make ends meet, despite working approximately fifty to sixty hours a week at her theater:

I drive Lyft part time, which is lucky that I have a car. I also work for a Kosher baker ... It's always really convenient because I start out like $5 \mathrm{am}$, I'm done by noon. I can be at the theater by 2 to work until midnight type situation. ${ }^{38}$ (Regan)

Regan was hired as an hourly employee but was converted to salary because her annual salary costs her theater less than paying hourly overtime. She works overtime every week but is no longer compensated for it. Comparing her annual salary against weekly hours worked and the theater's hourly wage, she says, "I get paid less than my concessionists." ${ }^{39}$ When we spoke, Regan had a job offer for a management position at a mainstream theater for double her current salary. "I don't want to work there, but if I can't get a \$5,000 raise then I have to" (Regan). Her theater has annual revenues over US\$4 million.

Jean, Director of Education at the Eastern Film Show, and Kitty, Director at the Eastern Cinema City, both worked outside exhibition prior to their current positions. Both took substantial pay cuts in the neo-art theater industry. They both noted the trade-off in salary comes in favor of independence and work flexibility, but as Melissa Gregg has shown, flex work can often lead to function creep and a deterioration in one's personal life. ${ }^{40}$ Indeed, both report having paid vacation time available and not utilizing it because of their work schedule and the feeling that they "can't take a day off."

Most of the women I interviewed report that their theater has no clear policy or system for professional or compensational advancement. Many report seeing small raises "appear" in their paychecks at random times. Moira (Western City Cinema) shared,

If you take on or if you are going to take on a new responsibility, sometimes you'll see a raise at the beginning at that new duty and sometimes you don't. Most recently, I took on a new project and I was not compensated for it. I asked for clear guidelines because I felt that that would have warranted a pay increase. I was not given any instruction or any guidelines or any kind of pathway for that. I was eventually compensated but I don't-it always felt like hush money. ${ }^{41}$

Moria's comment speaks to the disjunction between job roles, compensation, performance, and the informal or counterintuitive systems neo-art houses often use to remunerate labor. Many theaters do not have a formal review system in place to help guide advancement, and those who have received raises are unclear why they were granted their specific raise amount. While research has shown that performance reviews can reinforce gendered pay dipartites through performance-reward bias, ${ }^{42}$ having any type of systemized process increases transparency for workers, enabling them to better self-advocate. This is particularly true when theaters use performance reviews as an informal benchmark for compensation outside of a structured review process. For example, Betsey, CEO of The Western, explains how despite not having a formal performance review process, raises are based on performance reviews: 
There is more of an increase system than there is a performance review. Everybody gets a cost of living increase every year. Everybody just got raises and well no, almost everybody just got raises that were merit-based, I guess performance based. We don't have a ton in way of formal evaluation or systems ... everybody got a different percentage increase that was based on performance. My assessment of that. ${ }^{43}$ (Betsey)

With the exception of participants responsible for managing their theaters' budget, no one I spoke with had any idea of their colleagues' salaries, and therefore had less of the information necessary to advocate for their own financial solubility. As Jean said, "it's every man for themselves." 44

While benefits varied across theaters, all full-time staff reported receiving medical health care benefits; 73 percent received dental benefits and 47 percent received vision benefits. Only 47 percent reported their theater offering retirement benefits. With one exception, all the women I spoke with depend on their salaries to survive; independent or generational wealth was not a factor for them. The exception is a woman who accumulated wealth (cash and retirement savings) in a lucrative career before moving into the neo-art house. Retirement benefits are a crucial issue. With no retirement savings plans now or in the immediate future, half of the participants will rely on social security benefits in their later years. Indeed, 56 percent of all social security beneficiaries are women, ${ }^{45}$ and 20 percent of those women rely on Social Security for a majority of their income. ${ }^{46}$ Most of the participants will be eligible for benefits in 2047 or later, but by 2037 the program will have been so regularly underfunded that benefits will pay out only at 75 percent per year. ${ }^{47}$ Resultingly, study participants will be forced to support themselves on just over US\$10,000 in their elder years, 20 percent below the current poverty line in the United States. ${ }^{48}$ Women in the neo-art house are committing themselves to the industry's ideological culture while working themselves into future poverty.

Jobs without retirement benefits privilege upper- and middle-class individuals, as that class can subsidize overall compensation with other preexisting revenue sources. This tracks with the overall privileging of upper- and middle-class workers in the creative industries. ${ }^{49}$ Jobs without retirement benefits also privilege married individuals, who may be able to depend on their spouse to underwrite present low salaries and future retirement deficits. Women make less money overall than men, so lack of access to retirement benefits can disproportionally impact non-married women workers. These disparities may lead to less women working in the industry for significant periods of time, increasing turnover, limiting institutional memory, and potentially jeopardizing the maintenance and growth of the industry itself. Without an investment in the future of their employees, the neo-art house industry is benefiting from the work of a generation of women who may be unable to provide for their basic needs in retirement while also paying many of them less than a living wage in their prime working years-a stark departure from the industry's ideological culture. Operating outside of benchmarking or industry-wide standards siloes compensation and job function information, disempowering employees from actively advocating for themselves. Resultingly, salaries can be kept disproportionately low for gendered job functions, compressing pay year over year and increasing "greater economic inequality, insecurity, and instability." 
In addition to inequitable compensation, benefits, and job functions, the lack of trained and specific HR functions became particularly problematic in 2017 after high-profile, and widely reported, incidents of prolonged sexual assault and harassment at two of the premier neoart house theaters in the country. Those were, of course, not isolated events, and soon women across the industry began voicing their stores of hostile and abusive workspaces. These incidents exposed the broader trend of organizational inabilities to manage HR across financial, cultural, and bodily equity.

\section{Neo-Art House Reckoning}

In the fall of 2017, the neo-art house industry faced exposure to sexual abuse and harassment. Two incidents defined this issue. The first was the closing of Cinefamily in Los Angeles, a premier neo-art house theater, after multiple reports of workplace sexual abuse and harassment by its co-founder and executive director Hadrian Belove. Belove "has been accused of sexual harassment, assault, and abuse by former employees and volunteers. ${ }^{" 51}$ Cinefamily closed in November 2017 in the wake of the scandal. ${ }^{52}$

The second involved Alamo Drafthouse, arguably the most successful neo-art theater chain, with forty theaters across the United States. In 2016, Devin Faraci, editor-in-chief of Alamo's website Birth.Movies.Death and among the upper echelons of Alamo's Fantastic Fest film festival, resigned after accusations of workplace sexual assault. Despite this, Faraci was seen at Alamo events with employee credentials as soon as four months after resignation. ${ }^{53}$ In September 2017, news that Alamo CEO Tim League had quietly rehired Faraci ${ }^{54}$ without informing staff or Faraci's victims was met with intense criticism and anger. Within two days, he had resigned a second time. ${ }^{55}$

These incidents are not exceptions. Jean shared two experiences of harassment-one which escalated to stalking-by industry guests of her theater. ${ }^{56}$ Angelica shared a story of a man who would not leave her theater lobby until she gave him her phone number; she was too scared to say no. Paige recounted a struggle to get harassment claims taken seriously at her theater: "We had a programmer who was a disgusting misogynist pig. I filed two sexual harassment complaints against him, and nothing happened until the third one happened to one of my 22-year-old staffers. ${ }^{" 57}$ Regan, Paige's co-worker, remembers the response to the first complaint:

the executive director said well, we should change the dress code. To which we said, 'fuck you' and wore short shorts up our asses for the next two weeks. I deserve to be treated with respect no matter what my butt looks like. ${ }^{58}$

The industry was forced to reconcile what many already knew: neo-art house ideological culture does not spare gendered work from assault and harassment. This ideological mismatch was particularly unsettling to some. Anna Marie noted,

I want to think no! Of course, people that care about propping up films by women, and people of color, who provide queer perspectives, they obviously wouldn't do that! But we can see a number of situations wherein these people in positions and industries where they are supposed to be part 
of these liberal networks are failing at this. I wish it was surprising, but the patterns are showing that the political identity of liberalness isn't corresponding to people's behaviors. ${ }^{59}$

Paige echoed these sentiments succinctly: "I wasn't surprised. I was pretty disgusted."60 These feelings came to a head at the 2018 Convergence, which hosted a keynote panel with League "offering a mea culpa of sorts while focusing on the initiatives the organization has undertaken post-controversy to move forward." 61 Jean recounted an exchange after the panel where she was asked by a colleague about her harassment and stalking experiences:

All of a sudden I was like deer in the headlights. I'm talking about-this feels weird. Am I gossiping or am I calling out a man who was disrespectful to me and harassed me and stalked me? Why am I protecting this guy? It was fucked up how much I was actually still feeling it in the moment just this afternoon. ${ }^{62}$

Conversations like this exemplified how deeply the problem of sexual harassment has embedded itself into the neo-art house industry.

\section{Internal Industry Efforts: Alliance for Action}

Into this shifting landscape stepped Alliance for Action, a group of neo-art house workers striving to reorient the industry toward inclusivity, diversity, and equity. Alliance for Action, or A4A, was formed in 2017, and its mission statement reads,

Alliance for Action is a diverse group of individuals and organizations committed to undoing systems of oppression in the film industry by acting in allyship with people of all races, genders, religions, sexual orientations, socioeconomic statuses, physical abilities, ages, and all people experiencing oppression. We take action to present and promote programming that actively dismantles oppression and inequity in our communities. As a collective, we take risks, collaborate, and support each other as we strive to reduce and eliminate all forms of inequity in cinema. ${ }^{63}$

A4A has no institutional home; its 50+ members are scattered all over the country and meet over video calls. Responsibilities are delegated to working groups, decision-making is collective, and it is open to exhibitors, distributors, festivals, and all people who work in film exhibition. A4A targets AHC and the Convergence as the node in which neo-art house theaters interact. AHC's managing director is an A4A member, and A4A has begun integrating itself into the yearly Convergence. A4A represents the core of internal advocacy efforts in the neo-art house theater industry.

As an entity, A4A is what Tapia et al. call a supra-union structure: "organizations outside of traditional union structures that... have an emphasis on the intersectionality of worker identities in the framing of workers and campaign interests." ${ }^{64}$ Supra-unions benefit workers left out of traditional union structures and workers in atomized workspaces like neo-art house theaters. While union organizing often highlights class as a binding commonality, it does so at the expense of other identity factors, forgoing an intersectional approach to labor. Two of the most high-profile supra-unions are Fight for 15 and the Restaurant Opportunities Center, both working on behalf of fast-food restaurant employees. The Restaurant 
Opportunities Center is a particularly apt comparison for A4A as they both function as worker centers: "community-based organizations that use service, advocacy, and organizing to improve the living and working conditions of the workers and members." 65

As a worker center, A4A strives for collective change implementation through interface with AHC. A4A was first involved in the 2018 Convergence, facilitating panels on changing the culture in neo-art house theaters and outlining best practices to investigate and adjudicate reports of sexual harassment and abuse. As if testament to the need for the organizational evolution spurred on by A4A, participants on one of these panels insisted that theaters could still have "fun" while constructing safe working environments, implying that ensuring the bodily integrity of employees and fostering non-hostile workspaces are punishments that suppress "fun." ${ }^{\text {" B }}$ By the 2019 Convergence, they had "formed focus groups to develop a code of conduct, created a resource list, increased access to the convergence, and programmed workshops to encourage collective introspection and brainstorming for how to address biases and structural inequality." 67

While A4A has done admirable work, they have disconnected labor from gender, race, ethnicity, citizenship status, and other identity factors that intimately shape a person's working life. Unlike other supra-union organizations that focus on an intersectional construction of labor, the labor and economic disparity women neo-art house workers face have yet to explicitly intertwine with A4A's advocacy actions. This disconnect is not unique to A4A. In response to the issues of gendered economics and precarity outlined above, many participants echoed a common refrain along the lines of "I know that it's bad, but independent film is so important." Here, again, the ideological culture of neo-art house theaters, and their stated "specialness" and artistic importance are seen by workers as more critical than equitable labor conductions, living wages, and bodily integrity. Mission investment as cardinal to labor is common for creative or non-profit laborers. In a 2018 survey of non-profit workers, 78 percent of respondents said they work at their organization because of mission investment. ${ }^{68}$ Ideological investment, then, supersedes present and future employee welfare, even for the employee themselves, a type of self-exploitation Hesmondhalgh and Baker identify as detrimental to creative workers. ${ }^{69}$

The struggle for neo-art house worker and A4A is nestled in the irreconcilable differences between the idea of, commitment to, and reality of creative work-or what Miya Tokumitsu calls submitting to the "do what you love" mantra. ${ }^{70}$ When labor is sublimated to love (read: mission investment), it "leads not to salvation, but to the devaluation of actual work, including the very work it pretends to elevate-and more importantly, the dehumanization of the vast majority of laborers." 71 This abstracts labor from work, "making workers believe their labor serves the self and not the marketplace. ${ }^{72}$ Abstracting one's labor realities from workrelated advocacy is a psychic survival strategy, but one that obfuscates labor's intersection with inequality while replicating the structures of silence, precarity, and gendered economics in the neo-art house.

Since 2015, 55 percent of neo-art houses reported an increase in attendance, and 64 percent reported higher revenues, due in large part to the ability to raise charitable donations. ${ }^{73}$ Poised for a renaissance, neo-art house labor must invest in intersectional advocacy. As groups like A4A push for equity, neo-art houses must be held accountable for their operational structures. 
${ }^{1}$ Dr. Alicia Kozma combines a practical focus on media labor with critical inquiry to understand how media industries work, who works in them, and how the labor of media workers is constructed. She is the co-editor of ReFocus: The Films of Doris Wishman (Edinburgh UP) and the author of Radical Acts: The Labor of Filmmaking and the Cinema of Stephanie Rothman (Mississippi UP 2022). She is Chair and Assistant Professor of Communication and Media Studies at Washington College and holds a PhD in Communication and Media Studies from the Institute of Communication Research at the University of Illinois, Urbana-Champaign.

${ }^{2}$ Richard E. Caves, Creative Industries (Cambridge, MA: Harvard University Press, 200), 1.

${ }^{3}$ Mark Banks, "Craft Labour and Creative Industries," International Journal of Cultural Policy 16 (3, 2010): 305-21.

${ }^{4}$ I use the term exhibitive labor rather than exhibition or exhibitor labor to broaden the scope of work traditionally associated with film exhibition. Exhibition is historically descriptive of the act of screening a film in a movie theater, while exhibitor refers to the theater owner. Exhibitive, or that which serves exhibition, is inclusive of the broadened organizational work of the neo-art house past ownership or projection.

${ }^{5}$ Rosalind Gill, "Cool, Creative and Egalitarian? Exploring Gender in Project-Based New Media Work in Europe," Information, Communication \& Society 5 (1, 2002): 70-89.

${ }^{6}$ Seventh Art Stand is organized by distributor Abramorama, the neo-art house Northwest Film Forum, and filmmaker/activist Vivian Hua. It was made available to any theater that chose to participate. Mobile Movie Theater is a program of the neo-art house The Belcourt, and CinemaQ and CineLatinx are programs of neo-art house Denver Film.

${ }^{7}$ Gill, "Cool, Creative," 70.

${ }^{8}$ Mark Banks and Katie Milestone, "Individualization, Gender and Cultural Work," Gender, Work and Organization 18 (1, 2011): 73-89.

${ }^{9}$ Amara, interview with author, January 13, 2018.

${ }^{10}$ Miranda J. Banks, "Oral History and Media Industries," Cultural Studies 28 (4, 2014): 545-60.

11 Tino Balio, The Foreign Film Renaissance on American Screens 1946-1973 (Madison: Wisconsin University Press, 2010).

${ }^{12}$ While there are a group of art theaters that run associated film festivals, festivals are not a significant source of revenue.

${ }^{13}$ Balio, Foreign Film, 14.

${ }^{14}$ Balio, Foreign Film, 24.

${ }^{15}$ Ibid.

${ }^{16}$ Barbara Wilinsky, Sure Seaters: The Emergence of Art House Cinema (Minneapolis: University of Minnesota Press, 2001), 13.

17 Thomas Elsaesser, European Cinema: Face to Face with Hollywood (Amsterdam: Amsterdam University Press, 2005): 45.

${ }^{18}$ Brian Brooks, "Specialty Box Office 2017," Deadline.com, December 30, 2017, https://deadline.com/2017/12/specialty-box-office-2017-the-big-sick-is-high est-grosser-but-overall-results-flat-1202233848/. 
${ }^{19}$ Wilinsky, Sure Seaters, 5.

${ }^{20}$ Notable exceptions are art theater "chains" like Louis K. Sher's Art Theater Guild (1954-approx. 1971) and Alamo Drafthouse (1997-present).

${ }^{21}$ Alicia Kozma, "Downloading Soon to a Theater Near You: Digital Film, Local Exhibition, and the Death of $35 \mathrm{~mm}$," The Projector 18 (1, 2018): 39-69.

${ }^{22}$ David Bordwell, "Pandora's Digital Box: Art House, Smart House," Observations on Film Art, January 30, 2012, http://www.davidbordwell.net/blog/2012/01/30/ pandoras-digital-box-art-house-smart-house/.

${ }^{23}$ Kozma, "Downloading."

${ }^{24}$ Joan McGettigan, "From Auditorium to Art House: The Many Lives of the Hiway Theater," The Projector 18 (1, 2018): 15-29.

${ }^{25}$ Data Arts, "National Theater Operations Survey," December 8, 2017, https://cdp. app.box.com/s/mynrf77aasnkwacok5cwzk663dcvdyub.

${ }^{26}$ Art houses traditionally, and still do, rely heavily on part-time work, specifically for front-of-house and projectionist work.

${ }^{27}$ I observed this divide at the 2017 Convergence, and the 2018 information was taken from the program schedule. This is an imperfect measurement, but no quantifying statistics exist.

${ }^{28}$ Marlene Kim, "Employers' Estimates of Market Wages: Implications for Wage Discrimination in the U.S," Feminist Economics 6 (2, 2000): 97-114.

${ }^{29}$ Kim, "Employers."

${ }^{30}$ Metropolitan statistical areas (MSAs) are determined by the US Office of Management and Budget (OMB) and used by the Bureau of Labor Statics (BLS) for data collection, correlation, comparison, and other functions. According to the OMB, MSAs comprise at least one urban area with a population of fifty thousand people or more, plus adjunct geographies with a high degree of economic and social integration into the urban area based on commuting for work. MSAs include approximately 94 percent of the US population. See Office of Management and Budget, "Bulletin 18-03," last modified April 8, 2018, https://www.bls.gov/bls/omb-bulletin-18-03-reviseddelineations-of-metropolitan-statistical-areas.pdf. Colloquially, MSAs are referred to as the primary city and its surrounding "metro" area. For example, Washington, DC is a primary city and the Washington, DC "metro area" would include significant parts of the states of Maryland and Virginia.

31 Tessa, interview by author, February 21, 2018.

${ }^{32}$ Kim, "Employers," 100.

${ }^{33}$ Neena, interview by author, January 29, 2018.

${ }^{34}$ Arne L. Kalleberg, "Precarious Work, Insecure Workers: Employment Relations in Transition," American Sociological Review 74 (2009): 1-22.

${ }^{35}$ Gill, "Cool, Creative."

${ }^{36}$ Mark Banks, "Autonomy Guaranteed? Cultural Work and the "Art-Commerce Relation," Journal for Cultural Research 14 (3, 2010): 251-69.

${ }^{37}$ Bureau of Labor Statistics, "Median Annual Earnings by Sex, Race and Hispanic Ethnicity," US Department of Labor, https://www.dol.gov/wb/stats/earnings. htm\#earningsot (accessed March 3, 2018). 
${ }^{38}$ Regan, interview by author, January 17, 2018. Regan's reliance on the gig economy offers a perspective on rethinking front-of-house neo-art house labor as gig work. ${ }^{39}$ Ibid.

${ }^{40}$ Melissa Gregg, Work's Intimacy (Cambridge: Polity, 2011).

${ }^{41}$ Moira, interview with author, February 19, 2018.

${ }^{42}$ Emilio J. Castilla, "Gender, Race, and Meritocracy in Organizational Careers," American Journal of Sociology 133 (6, 2008): 1479-526.

${ }^{43}$ Betsey, interview with author, January 17, 2018.

${ }^{44}$ Jean, interview with author, January 16, 2018.

${ }^{45}$ Social Security Administration, "Fact Sheet Social Security: Social Security Is Important to Women," last modified November 2016, ssa.gov/news/press/factsheets/ss-customer/women-ret.pdf.

${ }^{46}$ Joan Entmacher and Katherine Gallagher Robbins, "Women and Social Security," National Women's Law Center, last modified February 2015, https://nwlc.org/ resources/women-and-social-security/.

${ }^{47}$ Stephen C. Goss, "The Future Financial Status of the Social Security Program," Social Security Bulletin 70 (3, 2010): 111-25.

${ }^{48}$ Office for the Assistant Secretary for Planning and Evaluation, "2020 Poverty Guidelines for the 48 Contiguous States and the District of Columbia," US Department of Health \& Human Services, last modified January 21, 2020, https:// aspe.hhs.gov/2020-poverty-guidelines.

${ }^{49}$ See Irena Grugulis and Dimitrinka Stoyanova, "Social Capital and Networks in Film and TV: Jobs for the Boys?," Organization Studies 33 (10, 2012): 1311-31; Doris Ruth Eikhof and Chris Warhurst, "The Promised Land? Why Social Inequalities Are Systemic in the Creative Industries," Employee Relations 35 (5, 2013): 495-508. https://doi.org/10.1108/ER-08-2012-0061.

${ }^{50}$ Kalleberg, "Precarious," 8.

${ }^{51}$ Dana Harris-Bridson and Eric Kohn, "Hadrian Belove Resigns from Cinefamily After Anonymous Email Alleges Sexual Harassment." IndieWire, August 22, 2017, https:// www.indiewire.com/2017/08/hadrian-belove-cinefamily-resigns-sexual-harras ment-1201868927/.

${ }^{52}$ Mark Olsen, "Following Scandal and Investigation, Cinefamily to Shut Down Permanently," The Los Angeles Times, November 14, 2017, https://www.latimes. com/entertainment/movies /la-et-mn-cinefamily-shuts-down-20171114-story. html.

${ }^{53}$ Seth Abramovitch, "Drafthouse Caught in Firestorm as Devin Faraci Breaks Silence." The Hollywood Reporter, September 14, 2017, https://www.hollywoodreporter.com/ news /drafthouse-caught-firestorm-as-devin-faraci-breaks-silence-1039241.

${ }^{54}$ Seth Abramovitch, "Fantastic Fest Programmer Quits Over Rehiring of Controversial Blogger Devin Faraci," The Hollywood Reporter, September 13, 2017, https://www. hollywoodreporter.com/news /fantastic-fest-programmer-quits-rehiring-con troversial-blogger-devin-faraci-1038541.

${ }^{55}$ Abramovitch, "Drafthouse."

${ }^{56}$ Jean, interview. 
${ }^{57}$ Paige, interview by author, January 16, 2018.

${ }^{58}$ Regan, interview.

${ }^{59}$ Anna Marie, interview by author, January 10, 2018.

${ }^{60}$ Paige, interview.

${ }^{61}$ Alicia Kozma, "Conference Report: Art House Convergence," Film Criticism 42 (3, 2018), http://dx.doi.org/10.3998/fc.13761232.0042.303.

62 Jean, interview.

${ }^{63}$ AHC Alliance for Action, "Mission Statement," Private Google Group, accessed April 21, 2019.

${ }^{64}$ Maite Tapia, Tamara L. Lee, and Mikhail Filipovitch, "Supra-union and Intersectional Organizing: An Examination of Two Prominent Cases in the Low-Wage US Restaurant Industry," Journal of Industrial Relations 59 (4, 2017): 487-509.

${ }^{65}$ Tapia et al., "Supra-union," 491.

${ }^{66}$ Kozma, "Conference."

${ }^{67}$ AHC Alliance for Action, "Year in Review," email to author, last modified January 4, 2019.

${ }^{68}$ TIAA, "TIAA 2018 Nonprofit Survey Executive Summary," https://www.tiaa.org/ public/pdf/nonprofit_survey_executive_summary.pdf (accessed April 3, 2019).

${ }^{69}$ David Hesmondhalgh and Sarah Baker, "Toward a Political Economy of Labor in the Media Industries," in The Handbook of Political Economy of Communications First Edition, ed. Janet Wasko, Graham Murdock, and Helena Sousa (London: Wiley Blackwell, 2011): 382-400.

${ }^{70}$ Miya Tokumitsu, "In the Name of Love," Jacobin, last modified January 12, 2014, https://www.jacobinmag.com/2014/01/in-the-name-of-love/.

71 Tokumitsu, "In the Name of Love."

${ }^{72}$ Ibid.

${ }^{73}$ Avenue ISR and SMU Data Arts, "AHC 2018 National Audience Study," last modified January 22, 2019, https://www.arthouseconvergence.org/wp-content/ uploads /2019/05/AHC-2018-National-Audience-Study-FINAL-REPORT.pdf.

\section{Bibliography}

Abramovitch, Seth. "Drafthouse Caught in Firestorm as Devin Faraci Breaks Silence." The Hollywood Reporter, September 14, 2017. https://www.hollywoodreporter.com/ news /drafthouse-caught-firestorm-as-devin-faraci-breaks-silence-1039241.

Abramovitch, Seth. "Fantastic Fest Programmer Quits Over Rehiring of Controversial Blogger Devin Faraci." The Hollywood Reporter, September 13, 2017. https://www.hollywoodreporter.com/news/fantastic-fest-programmer-quits-rehiring-controversial-blog ger-devin-faraci-1038541.

AHC Alliance for Action. "Mission Statement." Alliance for Action Google Group. Accessed April 21, 2019.

AHC Alliance for Action. "Year in Review." Email to author. Last modified January 4, 2019. 
Amara. Interview by author. January 13, 2018.

Avenue ISR and SMU Data Arts. "AHC 2018 National Audience Study." Last modified January 22, 2019. https://www.arthouseconvergence.org/wp-content/uploads/2019/05/ AHC-2018-National-Audience-Study-FINAL-REPORT.pdf.

Balio, Tino. The Foreign Film Renaissance on American Screens 1946-1973. Madison: University of Wisconsin Press, 2010.

Banks, Mark. "Autonomy Guaranteed? Cultural Work and the "Art-Commerce Relation." Journal for Cultural Research 14, no. 3 (July 2010): 251-69.

Banks, Mark. "Craft Labour and Creative Industries." International Journal of Cultural Policy 16, no. 3 (August 2010): 305-21.

Banks, Mark, and Katie Milestone. "Individualization, Gender and Cultural Work." Gender, Work and Organization 18, no. 1 (January 2011): 73-89.

Banks, Miranda J. "Oral History and Media Industries." Cultural Studies 28, no. 4 (2014): 545-60.

Betsey. Interview by author. January 17, 2018.

Bordwell, David. "Pandora's Digital Box: Art House, Smart House." Observations on Film Art, January 30, 2012. http://www.davidbordwell.net/blog/2012/01/30/pandorasdigital-box-art-house-smart-house/.

Brooks, Brian. "Specialty Box Office 2017," Deadline.com, December 30, 2017. https:// deadline.com/2017/12/specialty-box-office-2017-the-big-sick-is-highest-grosserbut-overall-results-flat-1202233848/.

Bureau of Labor Statistics. "Median Annual Earnings by Sex, Race and Hispanic Ethnicity." US Department of Labor. https://www.dol.gov/wb/stats/earnings.htm\#earningsot (accessed March 3, 2018).

Caves, Richard E. Creative Industries. Cambridge, MA: Harvard University Press, 2001.

Data Arts. "National Theater Operations Survey." Last modified December 8, 2017. https:// cdp.app.box.com/s /mynrf77aasnkwacok5cwzk663dcvdyub.

Elsaesser, Thomas. European Cinema: Face to Face with Hollywood. Amsterdam: Amsterdam University Press, 2005.

Entmacher, Joan, and Katherine Gallagher Robbins. "Women and Social Security." National Women's Law Center. Last modified February 2015. https://nwlc.org/resources / women-and-social-security/.

Gill, Rosalind. "Cool, Creative and Egalitarian? Exploring Gender in Project-Based New Media Work in Europe." Information, Communication E Society 5, no. 1 (2002): 70-89.

Goss, Stephen C. "The Future Financial Status of the Social Security Program," Social Security Bulletin 70, no. 3 (2010): 111-25.

Gregg, Melissa. Work's Intimacy. Cambridge: Polity, 2011. 
Harris-Bridson, Dana, and Eric Kohn. "Hadrian Belove Resigns from Cinefamily After Anonymous Email Alleges Sexual Harassment." IndieWire, August 22, 2017. https://www.indiewire.com/2017/08/hadrian-belove-cinefamily-resigns-sexualharrasment-1201868927/.

Hesmondhlagh, David, and Sarah Baker. "Toward a Political Economy of Labor in the Media Industries." In The Handbook of Political Economy of Communications First Edition, edited by Janet Wasko, Graham Murdock, and Helena Sousa, 382-400. London: Wiley Blackwell, 2011.

Kalleberg, Arne L. "Precarious Work, Insecure Workers: Employment Relations in Transition." American Sociological Review 74 (February 2009): 1-22.

Kim, Marlene. "Employers' Estimates of Market Wages: Implications for Wage Discrimination in the U.S." Feminist Economics 6, no. 2 (2000): 97-114.

Kozma, Alicia. "Downloading Soon to a Theater Near You: Digital Film, Local Exhibition, and the Death of 35mm." The Projector 18, no. 1 (Winter 2018): 39-69.

Kozma, Alicia. "Conference Report: Art House Convergence." Film Criticism 42, no. 3 (2018). http://dx.doi.org/10.3998/fc.13761232.0042.303.

Marie, Anna. Interview by author. January 10, 2018.

McGettigan, Joan. "From Auditorium to Art House: The Many Lives of the Hiway Theater." The Projector 18, no. 1 (Winter 2018): 15-29.

Moira. Interview by author. February 19, 2018.

Neena. Interview by author. January 29, 2018.

Office for the Assistant Secretary for Planning and Evaluation. "2020 Poverty Guidelines for the 48 Contiguous States and the District of Columbia," US Department of Health \& Human Services, last modified January 21, 2020. https://aspe.hhs.gov/2020poverty-guidelines.

Olsen, Mark. "Following Scandal and Investigation, Cinefamily to Shut Down Permanently." The Los Angeles Times, November 14, 2017. https://www.latimes.com/entertain ment/movies/la-et-mn-cinefamily-shuts-down-20171114-story.html.

Paige. Interview by author. January 16, 2018.

Regan. Interview by author. January 17, 2018.

Social Security Administration. "Fact Sheet Social Security: Social Security Is Important to Women." Last modified November 2016. ssa.gov/news/press/factsheets / ss-customer /women-ret.pdf.

Tandy. Interview by author. February 21, 2018.

Tapia, Maite, Tamara L. Lee, and Mikhail Filipovitch. "Supra-union and Intersectional Organizing: An Examination of Two Prominent Cases in the Low-Wage US Restaurant Industry." Journal of Industrial Relations 59, no. 4 (2017): 487-509. 
Tessa. Interview by author. February 21, 2018.

TIAA. “TIAA 2018 Nonprofit Survey Executive Summary." https://www.tiaa.org/public/ pdf/nonprofit_survey_executive_summary.pdf (accessed April 3, 2019).

Tokumitsu, Miya. "In the Name of Love." Jacobin. Last modified January 12, 2014. https:// www.jacobinmag.com/2014/01/in-the-name-of-love/.

Wilinsky, Barbara. Sure Seaters: The Emergence of Art House Cinema. Minneapolis: University of Minnesota Press, 2001. 
